\title{
Comparative study of oral micronucleated cell frequency in oral submucous fibrosis patients and healthy individuals
}

\author{
Koneru Anila ${ }^{1}$, Hallikeri Kaveri ${ }^{2}$, Venkatesh G. Naikmasur ${ }^{3}$ \\ ${ }^{1}$ Post graduate, Department of Oral and Maxillofacial Pathology, SDM College of Dental Sciences and Hospital. \\ ${ }^{2}$ Professor, Department of Oral and Maxillofacial Pathology, SDM College of Dental Sciences and Hospital. \\ ${ }^{3}$ Professor and Head, Department of Oral Medicine and Radiology, SDM College of Dental Sciences and Hospital.
}

Correspondence:

Department of Oral and Maxillofacial Pathology,

SDM College of Dental Sciences and Hospital,

Dharwad- 580009

Karnataka, India

Email:drcaveri2005@gmail.com

Anila K, Kaveri H, Naikmasur VG. Comparative study of oral micronucleated cell frequency in oral submucous fibrosis patients and healthy individuals. J Clin Exp Dent. 2011;3(3):e201-6. http://www.medicinaoral.com/odo/volumenes/v3i3/jcedv3i3p201.pdf

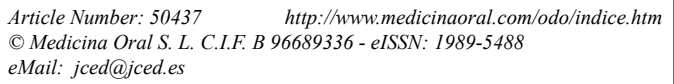

\begin{abstract}
Objectives: To determine the frequency of micronucleated cells and micronuclei in oral submucous fibrosis patients and to compare with healthy individuals.

Study design: Twenty patients with oral submucous fibrosis and twenty age-sex-matched healthy individuals as control group participated in this study. Exfoliated cells were obtained by scraping from right and left buccal mucosa and were screened for micronucleated cells and micronuclei. Frequencies were compared between oral submucous fibrosis and control group. Also comparison was made between chewing site and non-chewing site of buccal mucosa.

Results: Frequency of micronucleated cells and micronuclei in oral submucous fibrosis patients ranged from $0.6 \%$ to $5.3 \%$ and $0.50 \%$ to $5.74 \%$, where as in control group ranged from $0.5 \%$ to $0.9 \%$ and $0.22 \%$ to $0.88 \%$ respectively. Micronucleated cells and micronuclei in oral submucous fibrosis patients were statistically significantly elevated $(\mathrm{p}<0.05)$ as compared to control group. The mean percentage frequencies were higher on chewing site; however there was no statistically significant difference.

Conclusion: The present study revealed an increase in micronuclei in oral submucous fibrosis patients compared to healthy individuals. With gutkha chewing habit in younger age, chances of malignant transformation are high relatively. Thus micronuclei test can be used as an early indicator of genotoxicity in oral submucous fibrosis.
\end{abstract}

Key Words: Gutkha, micronuclei, oral submucous fibrosis, oral exfoliated cells, Papanicolaou stain (PAP). 


\section{Introduction}

Oral submucous fibrosis is an insidious, chronic disease which was first described in the early 1950s (1). It is characterized by changes in the connective tissue fibers of the lamina propria and deeper parts leading to stiffness of the mucosa and restricted mouth opening (2). This disease is predominantly seen in India, Bangladesh, Sri Lanka, Pakistan, Taiwan, China and among other Asiatics, with a reported prevalence ranging up to $0.4 \%$ in Indian rural population (1).

Studies have shown that areca nut as the major etiological factor in the pathogenesis of OSMF. There are regional variations in the type of areca nut products used in India and betel quid was the most popular and prevalent habit in ancient Indian culture (3). However in recent times, both areca quid (AQ) products such as pan masala and gutkha (AQ and tobacco) are introduced in Indian market.

Habitual gutkha users have shown to present with OSMF at earlier ages compared with traditional betel quid users. A gutkha sachet weighs $\sim 3.5 \mathrm{~g}$ and contains $7 \%$ moisture, whereas the net weight of a betel quid is nearly $4 \mathrm{~g}$ (with $\sim 1.14 \mathrm{~g}$ of tobacco) and contains $70 \%$ moisture. Because gutkha users tend to consume more dry weight of tobacco, areca nut, and slaked lime, they may be exposed to OSMF at earlier ages compared to other types of betel quid users (4).

OSMF is a well-recognized potentially malignant condition. Malignant transformation rate was found to be in the range of $7-13 \%$. According to long term follow-up studies a transformation rate of $7.6 \%$ over a period of 17 years was reported (5).

To evaluate the genotoxic risks or effects of gutkha users in OSMF, DNA damages can be assessed by chromosomal aberrations, sister chromatid exchanges and micronucleus (MN) test. Out of all these, MN test is found to be most sensitive, non invasive and very economical procedure (6). Thus, micronucleus in a cell represents an "internal dosimeter" to estimate exposure to genotoxic and carcinogenic agents.

The aim of the present study was to determine the frequency of micronucleated cells (MNC) and $\mathrm{MN}$ in OSMF and to compare with the healthy individuals.

\section{Methods}

The study comprised of a total of forty cases of both the sex. The patients were selected from among those visiting the Outpatient Department of Oral medicine and radiology, SDM Dental College and Hospital, Dharwad. The study protocol has been approved by institutional ethical committee.

The study group comprised of twenty cases of oral submucous fibrosis and twenty cases of age and sex matched healthy individuals as control group. Informed consent was obtained from all participants prior to inclusion in the study.

A detailed history was obtained from each participant with particular reference to type of chewing habit, duration of chewing, frequency of chewing and site of chewing. Clinical examination of the subjects was performed examining several factors. The degree of mouth opening (MO) was measured to determine the clinical staging in OSMF.

\section{Sampling of Exfoliated Cells:}

For the screening of micronuclei, exfoliated cells were obtained by scraping the buccal mucosa with a sterile spatula. Prior to sampling, all participants were asked to rinse their mouths with water to remove residual food particles. The cells were transferred directly onto a precleaned microscopic slide, allowed to air-dry, and then fixed in 70\% isopropyl alcohol.

Quantitating Micronucleated Cells:

The cytoplasmic assessment was performed by two authors in blinded fashion. Fixed smear were stained by

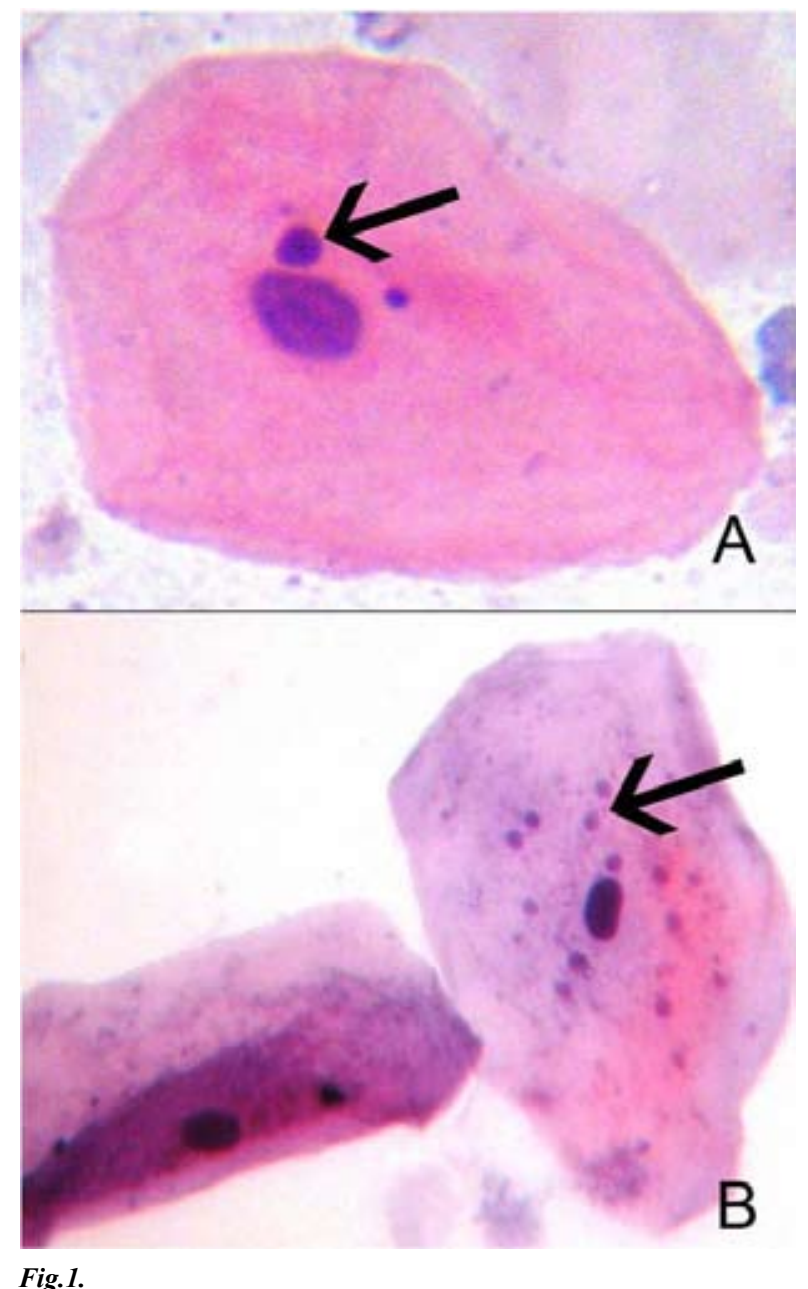

A: Exfoliated buccal cell showing two micronuclei surrounding the prominent nucleus. (PAP, 400x)

$B$ : Exfoliated buccal cell showing $\sim 10$ micronuclei surrounding the nucleus. (PAP, 400x) 


\begin{tabular}{llllllll}
\hline & $\begin{array}{l}\text { Chewing } \\
\text { habit }\end{array}$ & & $\begin{array}{l}\text { Duration } \\
\text { of habit }\end{array}$ & & $\begin{array}{l}\text { Amount of } \\
\text { Gutkha }\end{array}$ & $\begin{array}{l}\text { Site of } \\
\text { chewing }\end{array}$ \\
\hline Gutkha & 18 & $1-10 \mathrm{yrs}$ & 16 & $1-10$ pouches & 4 & Right buccal mucosa & 10 \\
\hline Areca nut & 2 & $11-20 \mathrm{yrs}$ & 4 & $11-20$ pouches & 16 & Left buccal mucosa & 10 \\
\hline Total & 20 & Total & 20 & Total & 20 & Total & 20 \\
\hline
\end{tabular}

Table 1. Distribution of patients with oral submucous fibrosis according to the type of chewing habit, duration of habit, amount of gutkha and site of chewing

Papanicolaou stain and counterstained with Harris hematoxylin. All the slides were observed under light microscope using low magnification $(\times 100)$ for screening and high magnification $(\times 400)$ for counting of micronuclei.

The most commonly used method was zigzag method for screening of the slides. Cells with intact nuclei and cell boundaries were counted. A total of 1000 cells were counted in the smear from right and left buccal mucosa of each patient for the presence and number of MNC and number of $\mathrm{MN}$ in each cell. The criteria for designating an extranuclear body as micronucleus (Fig.1) were given by Stich et al. (7) The percentage frequencies of $\mathrm{MNC}$ and $\mathrm{MN}$ were recorded. Comparison was done between OSMF group and control group. Furthermore comparison was also done between chewing site and non-chewing site in OSMF group.

The statistical evaluation of the data obtained was done using unpaired $t$ test. P value $<0.05$ is considered statistically significant.

\section{Results}

Patients characteristics:

The mean age of the test and the control group was 26.7 years and predominantly males $(18 / 20)$. Of twenty patients with OSMF, 18 patients $(90 \%)$ chewed gutkha (areca nut, catechu, cardamom, lime, chewing tobacco and artificial flavors) and only 2 patients $(10 \%)$ chewed areca nut alone. The type of habit, duration of chewing, amount of gutkha, site of chewing are shown in Table 1.
The duration of addiction of the chewing habit in sixteen patients was in average of one to ten years, and in them maximum number of patients developed OSMF in one-two years. Majority of the patients (16/20 patients) chewed gutkha with a frequency of 11-20 pouches per day for 5 to 10 minutes. In twenty cases with OSMF, ten cases chewed gutkha on right side and ten cases on left side of buccal mucosa.

The average mouth opening of the patients with OSMF was $19.75 \mathrm{~mm}$ as measured from upper to lower central incisor. Out of twenty cases with OSMF, on clinical staging 3 cases were in group I, 11 cases were in group II, 5 cases were in group III and 1 case was in group IV respectively.

Micronucleated cells:

The frequency of MNC and $\mathrm{MN}$ in OSMF group ranged from $0.6 \%$ to $5.3 \%$ and $0.50 \%$ to $5.74 \%$ respectively, where as frequency of $\mathrm{MNC}$ and $\mathrm{MN}$ in control group ranged from $0.5 \%$ to $0.9 \%$ and $0.22 \%$ to $0.88 \%$ respectively. The mean percentage frequencies of $\mathrm{MNC}$ and $\mathrm{MN}$ in OSMF patients and normal controls are shown in Table 2, Table 3. Using an unpaired-t test, it was found that both MNC and MN frequency in OSMF patients were statistically significantly elevated $(p<0.05)$ as compared to that in control group.

Comparison was done between chewing side and nonchewing side of buccal mucosa. The mean percentage frequencies were higher on chewing side than on nonchewing side of buccal mucosa; however there was no statistically significant difference between the two

\begin{tabular}{llllllll}
\hline Group & $\begin{array}{l}\text { No of } \\
\text { cases }\end{array}$ & $\begin{array}{l}\text { MNC } \\
\text { range\% }\end{array}$ & $\begin{array}{l}\text { Mean } \\
\text { MNC\% }\end{array}$ & $\begin{array}{l}\text { Standard } \\
\text { deviation MNC }\end{array}$ & t value & $\begin{array}{l}\text { P } \\
\text { value }\end{array}$ & Significance \\
\hline OSMF & 20 & $0.6-5.3 \%$ & 1.7160 & 1.4177 & -4.1319 & 0.0002 & $\mathrm{~S}$ \\
\hline Control & 20 & $0.5-0.9 \%$ & 0.3930 & 0.2013 & & \\
\hline
\end{tabular}

MNC - Micronucleated cells. OSMF- Oral submucous fibrosis

Table 2. Comparison of Mean and Standard deviation of MNC frequencies between OSMF and control group

\begin{tabular}{llllllll}
\hline Group & No of cases & MN range\% & Mean MN\% & $\begin{array}{l}\text { Standard } \\
\text { deviation }\end{array}$ & t value & P value & Significance \\
\hline OSMF & 20 & $0.50-5.74$ & 1.9395 & 1.4327 & -4.6736 & 0.0000 & $\mathrm{~S}$ \\
\hline Control & 20 & $0.22-0.80$ & 0.4208 & 0.2435 & & \\
\hline
\end{tabular}

MN - Micronuclei. OSMF- Oral submucous fibrosis

Table 3. Comparison of Mean and Standard deviation of MN frequencies between OSMF and control group: 


\begin{tabular}{lllllll}
\hline OSMF & No of cases & $\begin{array}{l}\text { Mean } \\
\text { MNC\% }\end{array}$ & $\begin{array}{l}\text { Standard deviation } \\
\text { MNC\% }\end{array}$ & t value & P value & Significance \\
\hline Chewing side & 10 & 1.8780 & 1.2782 & 0.7101 & 0.4820 & NS \\
\hline Non -chewing & 10 & 1.5795 & 1.3785 & & \\
\hline
\end{tabular}

MNC - Micronucleated cells. OSMF - Oral submucous fibrosis

Table 4. Comparison of Mean and Standard deviation of MNC frequencies between chewing and non-chewing side in OSMF group

groups, which is shown in Table 4.

Comparison of clinical staging in OSMF with micronuclei was also done. Frequencies of micronuclei in different clinical stages were observed to be as follows- 3 cases in group I showed mean percentage MNC frequency of $1.0433 \%, 11$ cases in group II showed $1.6545 \%, 5$ cases in group III showed $1.956 \%$ and 1 case in group IV showed 5.3\% respectively. The frequency of micronuclei was observed to increase from group I to group IV. However comparison of clinical staging with micronuclei frequency could not be studied statistically, because of unequal sample size in each group of clinical staging (Fig.2).

\section{Discussion}

Gutkha chewing is a popular oral habit with potential links to the occurrence of oral cancer (4). Many studies reveal that areca nut extract may demonstrate mutagenic and genotoxic effects, in addition to inducing preneoplastic as well as neoplastic lesions of oral cavity. Reactive oxygen species produced during auto-oxidation of areca nut polyphenols are crucial in the initiation and promotion of oral cancer (8).
These carcinogenic agents induce various kinds of DNA damage. Current predictive indicators of DNA damage are chromosomal aberrations and micronuclei. A micronucleus is a small extra nucleus separated from the main nucleus and is generated during cellular division when a chromosome fragments or divides late. Micronucleus assay has been used to determine the genotoxic and mutagenic potentials of various physical and chemical agents which could lead to the production of micronuclei (6). An early diagnostic test would be highly beneficial to check the progress of OSMF to squamous cell carcinoma, as shown that pre-malignancy occurs much before malignancy. Buccal mucosa is seen to be the most affected, as it is the most accessible site in the oral cavity, and its covering epithelium is non-keratinized. In addition, more surface area of the mucosa is exposed to the insults in the oral cavity, making it more vulnerable to changes.

Majority of the studies from 1985 till date have shown significant increase in $\mathrm{MN}$ in buccal exfoliated cells in chewers of betel quid compared to healthy individuals (9). In addition frequency of micronuclei was significantly higher in smokers with chewing a mixture of be-

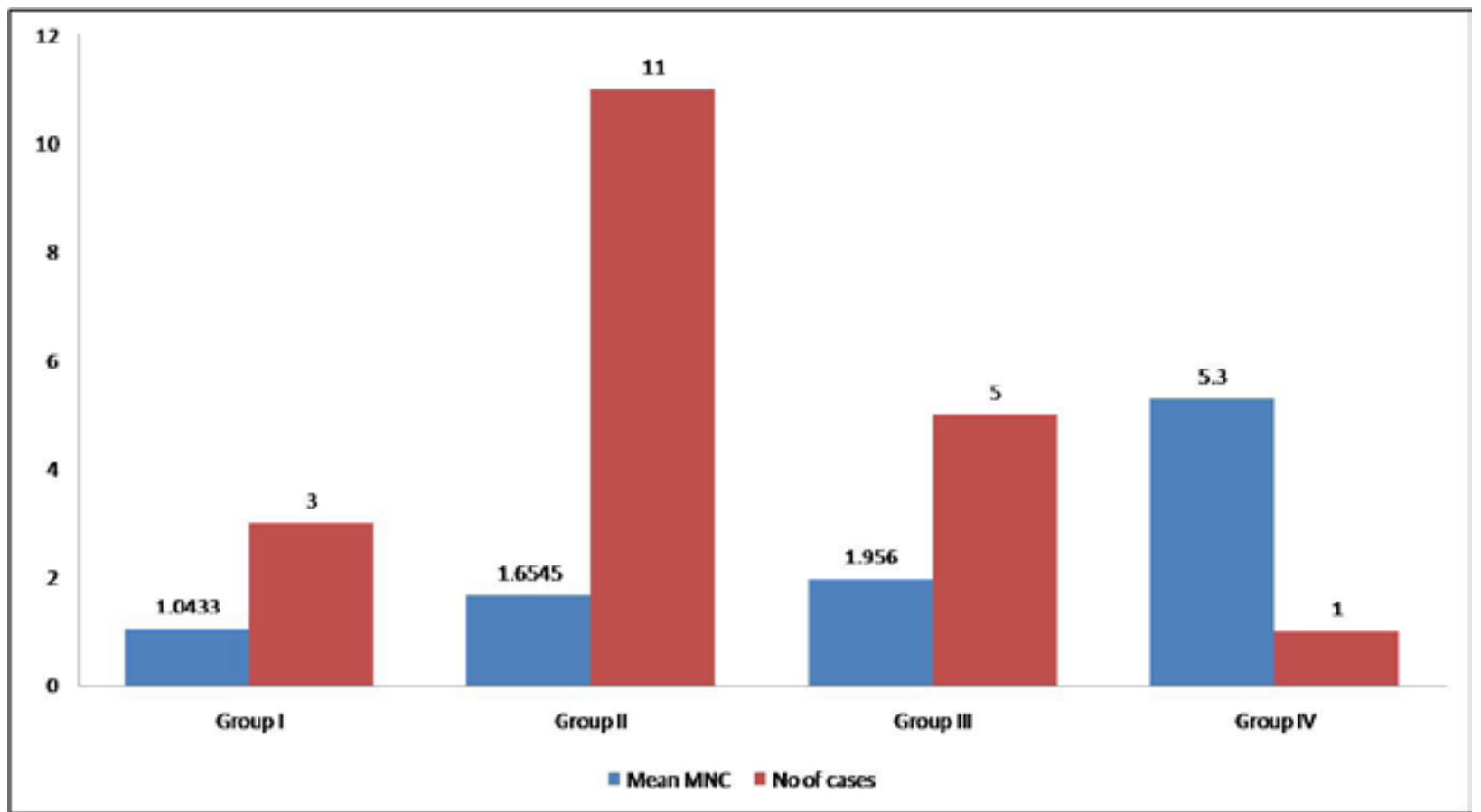

Fig.2. Comparison of Mean Micronucleated cell frequencies with clinical staging in OSMF. 
tel leaf, areca nut and tobacco than that in chewers who did not smoke $(10,11)$.

In the present study, frequency range of $0.5 \%-0.9 \%$ of $\mathrm{MNC}$ and $0.22 \%-0.80 \%$ of $\mathrm{MN}$ and mean percentage of $\mathrm{MNC}$ and $\mathrm{MN}$ of 0.3930 and 0.4208 respectively, was obtained for the control group (Table 2 and 3 ). Regional variation is seen in the mean percentage of micronucleated cells in normal populations as shown by the different values in different studies. Stich et al. (7) showed the mean percentage of MNC in the buccal mucosa of controls in Orissa population as 0.39 and $0.44 \%$ in the populations of Meghalaya. The difference in the frequencies of micronucleated cells in the control group could be due to the different food habits of the population groups studied. Man ingests various types of mutagens and/or carcinogens in his daily diet, and that could be the reason for the variable level of micronucleated cells (6).

In the present study, OSMF group showed MNC and MN range of $0.6-5.3 \%$ and $0.50-5.74 \%$ respectively (Table 2 and 3). There was increase in mean percentage of MNC and $\mathrm{MN}$ in OSMF patients of $1.7160 \%$ and $1.9395 \%$ as compared to the control group and showed statistically significant difference between the two groups $(\mathrm{p}<0.05)$. In addition, increased frequency of cells containing multiple micronuclei in OSMF was observed. These observations indicate genetic damage, which correlates with precancerous nature of OSMF predisposing to malignant transformation.

Desai et al. (12) also reported similar results in a study conducted on the exfoliated cells of patients with precancerous oral lesions, like oral submucous fibrosis, leukoplakia and lichen planus. They showed a highly significant increase in the mean micronucleated cells in OSMF as compared to their control group. Similar results were also seen in study done by Saran et al. (13)

Ahmad et al. (14) has shown strong association of gutkha with OSMF. Gutkha chewing produced OSMF in a very shorter duration of 4years as compared to raw areca nut and other products like pan and pan masala. Similarly in the present study maximum patients chewed gutkha and developed symptoms of OSMF within 1-2 years with frequency of 11-20 pouches per day.

A comparison was also made between the mean percentage frequency of MNC and MN in OSMF depending on the site of gutkha placement i.e. chewing site and nonchewing site of buccal mucosa (Table 4). The micronucleated cell counts were found to be higher in chewing site compared to the non-chewing site; however there was no statistically significant difference. The involvement of gutkha containing areca nut and tobacco in the induction of micronucleated cells can also be deduced from the higher frequencies of mean percentage MNs at the site at which gutkha product is placed as compared to the opposite non-chewing site in the oral cavity. However the presence of MNC in the non-chewing site could be due to the distribution of genotoxic agents through saliva. Similar results were obtained in a study comparing the habit of tobacco placement in affected and unaffected site and showed increase in MNC in affected site where the tobacco product was constantly placed (6).

Frequency of $\mathrm{MNC}$ and $\mathrm{MN}$ were increased with increase in clinical staging (Fig.2). However comparison of clinical staging with micronuclei frequency could not be studied statistically. One case of OSMF in group IV clinical staging showed mean MNC of 5.3. This might probably notify that there is malignant transformation taking place. Comparing of clinical staging of OSMF with micronuclei in our study is found to be the first study in literature, although studies with comparison of clinical staging in squamous cell carcinoma with micronuclei are available (15).

The variations in the micronucleated cells may be attributed to the factors like ingredients in the quid, the number of quids per day and different lifestyles, gender, age and food habits (16).

Although OSMF is irreversible and persists even after cessation of the chewing habit, it may be hypothesized that cessation of the gutkha-chewing habit may help to reduce the severity of the condition and may also prevent its progression to malignancy. To conclude from this stu$\mathrm{dy}$, the noninvasive screening technique can be used for management of subjects under carcinogenic risks after exposure to genotoxic agents.

By raising awareness about the negative effects of gutkha, the prevalence of OSMF and oral cancer might decrease among adolescents. This may also assist in improving the quality of life in these individuals.

\section{References}

1. Murti PR, Bhonsle RB, Gupta PC, Daftary DK, Pindborg JJ, Mehta FS. Etiology of oral submucous fibrosis with special reference to the role of areca nut chewing. J Oral Pathol Med. 1995; 24: 14552.

2. Tilakaratne WM, Klinikowski MF, Saku T, Peters TJ, Warnakulasuriya S. Oral submucous fibrosis: review on aetiology and pathogenesis. Oral Oncol. 2006; 42:561-8.

3. Hazare VK, Goel RR, Gupta PC. Oral submucous fibrosis, areca nut and pan masala use: a case control study. Natl Med J India. 1998; 11: 299.

4. Javed F, Chotai M, Mehmood A, Almas K. Oral mucosal disorders associated with habitual gutka usage: a review. Oral Surg Oral Med Oral Pathol Oral Radiol Endod. 2010; 109:857-64.

5. Murti PR, Bhonsle RB, Pindborg JJ, Daftary DK, Gupta PC, Mehta FS. Malignant transformation rates in oral submucous fibrosis over a 17-year period. Community Dent Oral Epidemiol. 1985; 13:340-1.

6. Kamboj M, Mahajan S. Micronucleus - an upcoming marker of genotoxic damage. Clin Oral Investig. 2007; 11:121-6.

7. Stich HF, Stich W, Parida BB. Elevated frequency of micronucleated cells in the buccal mucosa of individuals at high risk for oral cancer: Betel quid chewers. Cancer Lett 1982; 17:125-134.

8. Jeng JH, Chang MC, Hahn LJ. Role of areca nut in betel quidassociated chemical carcinogenesis: current awareness and future perspectives. Oral Oncol. 2001; 37:477-92.

9. Nair U, Obe G, Nair J, Maru GB, Bhide SV, Pieper R, et al. Evaluation of frequency of micronucleated oral mucosa cells as a marker 
for genotoxic damage in chewers of betel quid with or without tobacco. Mutat Res. 1991; 261: 163- 168.

10. Sellappa S, Balakrishnan M, Raman S, Palanisamy S. Induction of micronuclei in buccal mucosa on chewing a mixture of betel leaf, areca nut and tobacco. J Oral Sci. 2009; 51:289-92.

11. Proia NK, Paszkiewicz GM, Nasca MA, Franke GE, Pauly JL. Smoking and smokeless tobacco-associated human buccal cell mutations and their association with oral cancer - a review. Cancer Epidemiol Biomarkers Prev. 2006; 15: 1061-77.

12. Desai SS, Ghaisas SD, Jakhi SD, Bhide SV. Cytogenetic damage in exfoliated oral mucosal cells and circulating lymphocytes of patients suffering from precancerous oral lesions. Cancer Lett. 1996; 109:9-14.

13. Saran R, Tiwari RK, Reddy PP, Ahuja YR. Risk assessment of oral cancer in patients with pre-cancerous states of the oral cavity using micronucleus test and challenge assay. Oral Oncol. 2008; 44:354 60.

14. Ahmad MS, Ali SA. Chaubey KK. Epidemiological and etiological study of oral submucous fibrosis among gutkha chewers of Patna, Bihar, India. J Indian Soc Pedod Prev Dent. 2006; 6:84-9.

15. de Carvalho MB, Ramirez A, Gattás GJ, Guedes AL, Amar A, Rapoport A et al. Relationship between the outcome and the frequency of micronuclei in cells of patients with oral and oropharyngeal carcinoma. 2002; 48:317-22.

16. Holland N, Bolognesi C, Kirsch-Volders M, Bonassi S, Zeiger E, Knasmueller $\mathrm{S}$, et al. The micronucleus assay in human buccal cells as a tool for biomonitoring DNA damage: the HUMN project perspective on current status and knowledge gaps. Mutat Res 2008; 659:93-108. 